\title{
Women and Poverty (a Study in Foreign TKW in Tulung Agung Regency)
}

\section{Sayekti Suindyah D. ${ }^{1}$, Andi Reni ${ }^{2}$, Titin ${ }^{3}$, Tatik Mulyati ${ }^{4}$ and Muhammad Yusuf ${ }^{5}$}

${ }^{1}$ University of Darul 'Ulum Jombang, Indonesia, e-mail: sayekti.fps@mail.undar.ac.id

${ }^{2}$ Hasanuddin University, Indonesia, e-mail: andirenireni@gmail.com

${ }^{3}$ Lamongan Islamic University, Indonesia, e-mail: Titinunisla543@gmail.com

${ }^{4}$ University of Merdeka Madiun, Indonesia, e-mail: tatikmulyati@unmer-madiun.ac.id

${ }^{5}$ Science and Technology Institute AKPRIND Yogyakarta, Indonesia, e-mail: yusuf@akprind.ac.id

\begin{abstract}
The objectives of this research are: (1) to find out the comparison of TKW life before and after becoming TKW, (2) to know and to examine the problems faced by former TKW, the analytical method used is a qualitative method by using Forum Group Discussion (FGD). The results of the research are: (1) the economic condition of the ex-migrant workers after no longer TKW economic condition is short of $62.56 \%$, enough as much as $12.16 \%$, both as much as $4.25 \%$ and better as much as $21.62 \%$ of all respondents. (2) problems faced by ex-migrant workers, among others: (1) Economic condition returning to the period before leaving for TKW. (2) There is no concern from the government towards the migrant workers who are no longer TKW, (3) the difficulty of finding employment or business field in their own country, (4) Physical which no longer guarantees them to keep working as TKW. (5)Lack of appreciation given by the government after they are no longer TKW. (6) Their trauma to become TKW again. (7) Unstable economic conditions in the State of Indonesia. (8) The quality of human resources is still low.(9) High cost or cost to become TKW. (10) Often used as an object of dispute by the government at home and abroad. (11) Ineffective protection for migrant workers working overseas in obtaining a sense of security and comfort in working. How the former TKW overcome the problem by opening their own business, working in the agricultural sector, so housekeepers and so forth. The Government's way to overcome the problem of ex-migrant workers by providing business capital and empowerment in the economic sector.
\end{abstract}

Keywords: Woman, Poverty, Former TKW, TKI.

\section{Introduction}

The World commemorates 17 October as International Poverty Eradication Day. This warning is marked by the decision of the United Nations General Assembly to adopt UN resolutions. 47/196 on December 22, 1992. The world recognizes that free from poverty, prosperous life and human dignity is the fulfillment of human rights, as well as the pursuit of a sustainable human future.

Indonesia has the same concerns, one of which is realized by ratifying the Convention on the Elimination of All Forms of Discrimination Against Women (CEDAW), through Law No. 7 of 1984, where Article 14 CEDAW regulates the elimination of discrimination against Women in Rural Areas. As a member of the United Nations, Indonesia is also bound to implement UN Resolution 62/136 (February 12, 2008) on Enhancing the Situation of Women in Rural Areas.

The problem of poverty is the root of the problem that has a very wide impact on improving the quality of life of women, welfare and child protection such as trafficking of women and children, decreasing health status and dropping out of education. Poverty in Indonesia today, is deep poverty situations occur that are multidimensional.

Based on the data of the Indonesian poverty line in 2013 of Rp 275,779 / capita / month, in 2014 of Rp 296,681 / capita / month, 2015 of Rp 333,034 / capita / month, 2016 of Rp 350,420 / capita / month and 2017 of 370,910 / capita / month. This data is calculated in the 2nd semester of September each year. Similarly, poverty line data in East Java province in 2013 amounted to Rp 264,632 / capita / month, in 2014 of Rp 296,241 / capita / month, in 2015 amounting to Rp 336,592 / capita / month, in 2016 of Rp 351,708 / capita / month and year 2017 of Rp 373,039 / capita / month. (BPS, 2017a). 
The development of Gender Development Index data in East Java from 2010 to 2015 increased by $88.80 \%$ in 2010 to $91.07 \%$ in 2015. Similarly, the development of Gender Empowerment Index data in East Java is fluctuating, which was $67.91 \%$ in 2010, increased to $70.77 \%$ in 2013 and from 2014 until 2015 decreased to $68.41 \%$ (BPS, 2017a).

The inequality of job opportunities is a big problem that until now there is still no way out that can be given by the government to overcome the problem. This inequality is evident in the development of the workforce that goes much more rapidly than the ability of employment. Nationally, in urban areas, the total working population is greater than in rural areas, i.e. $89.12 \%$ (in urban areas) and $10.88 \%$ (in rural areas). Meanwhile, the main employment of the highest population is in the agricultural sector $(33.40 \%)$, large trading, retail, restaurant hotel $(22.79 \%)$ and manufacturing industry $(15.01 \%)$ (BPS, 2017c).

Although the percentage of the full-time working population is larger in urban areas, the main employment sector is more dominant in pedestrian (this is seen from geographic). With the inclusion of modern agricultural and non-agricultural technology in the countryside has resulted in reduced employment, because with modern technology resulted in the replacement of human working capital into working capital machines. Total search, female sex as much as 371050 people in 2016, this amount is more than the job seekers male sex, as many as 275364 people (CBS, 2017b)

The increasingly narrow land conditions, the inclusion of modern equipment in the agricultural sector that took over the role of humans in working into the role of machinery and the wage gap between in cities and in villages for those working outside the agricultural sector, further suppressed rural populations to migrate to urban areas. Promising conditions to work outside the countryside cause rural residents to migrate to the city especially to Jakarta. However, the reality of living in Jakarta is more difficult than living in rural areas. This is what causes rural residents to think again to migrate to Jakarta, there are even residents who decide to work abroad because abroad is more promising with higher salaries/wages than working in Indonesia. One of the regions or regions that contributed the most in sending its workforce abroad is Tulung Agung District. i.e. as many as 3,000 of these TKW from January to mid-2014. And in the year 2013, Tulung Agung District dispatched as many as 4,500 people. And the total number of TKW from Tulung Agung regency registered in Dinsosnakertrans of Tulung Agung Regency reaches more than 35,000 people (http://www.beritasatu.com/nasiona1/189370_Total of TKW-origin-TulungAgung-keepincreasing.html (accessed, Monday, March 12, 2018).

Indonesian workers who work both men and women will earn income. And their income is sent back to his hometown to be managed by the family he left behind (husband/wife/child/parent). The income earned by migrant workers sent to their hometown is mostly used to finance the family life of the migrant workers and if there is any remaining money will be bought land, house or pets.

But the fact that happened, there are some migrant workers who after working in Foreign Affairs, because age is not possible to go back to work abroad then they decided to live again in his hometown what happened? Some of them are no longer able to have the results of their efforts, even they become poor again because all the income they earn has been spent consumptive and no one saved. Based on the background that has been described, the researchers want to conduct research with the title "Women and Poverty (a study on Former TKW in Tulung Agung District)".

The formulation of the problem in this research are: (1) How to compare the life of TKW before, when and after becoming TKW. (2) What are the problems faced by former TKW? Purposes of this research are: (1) to find out the comparison of TKW life before and after becoming TKW, (2) to know and to examine the problems faced by former TKW.

The research conducted by Kodwo Ewusi in Ghana (1971) concludes that social circumstances are too pressing to encourage people to move (Tjiptoherijanto, 1982). In June 1972, Bappenas conducted a study to find out why migrants moved to Jakarta. (Kuntjoro-Jakti, 1986). The study was conducted on 3,197 randomly selected migrants in Jakarta. And 83\% of them say they have never been to Jakarta before. The migrants originally came to Jakarta with an estimate would stay for a while. But this 
thought changed and soon they decided to settle in Jakarta with the excuse of having no trouble getting a job in Jakarta. This number reaches $60 \%$ of the sample migrants.

The Research conducted by Nizar, Hamzah and Syahnur, (2013) resulted that the influence of economic growth estimation on poverty level is also not so great but related with negative and significant. Research conducted by Kiauši ene, Ilona (2015) results in female unemployment and inter-relation, and unemployment is one of the causes of poverty. Latifah's research (2010) resulted in poverty policy in Indonesia, not in line with MDG's target. Sayekti (2016) resulted in the study that the condition of the former TKW in Tulung Agung district after no longer become TKW again as before.

The meaning of Indonesian labor is Indonesian migrant workers who work abroad in the informal sector, especially in the domestic area. The Indonesian workforce consists of female and male laborers. Women workers who come from Indonesia, most of whom work abroad in the informal sector, are as housemaids. While the male labor force most of them work as chauffeurs and rough labor because the condition is often experienced various problems that must be faced, such as physical violence, discriminatory treatment of women, wages not paid by PJTKW and fraud by PJTKW and so forth.

\section{Research Methodology}

This research was conducted directly to the field by doing Forum Group Discussion (FDG). FDG is done by forming discussion groups that fit the age criteria. This FDG is done twice. namely FDG for groups (1) ages 21-30 years and 31-40 years, group (2) ages 41-50 years and age 51-6 0 years. The type of research used is survey research. The reason this village was chosen to be a place of research because almost most of the TKW originating from Tulung Agung came from the village. This research will be conducted for six months, i.e. month April up to December 2017.

Sources of data used in this study are (1) Primary Data, i.e. data obtained by providing a list of questions to the respondent (former TKW). (2) Secondary Data, i.e. data obtained from institutions or agencies related to this research. Data collection will be done by using: (1) Interview, (2) Questionnaire, (3) Observation, (4) Library Studies. After the data collected, then the next step is to tabulate the data obtained from respondents or from agencies or institutions associated with this research. After the tabulation, the next step is to perform data analysis to answer the research objectives, among others: (1) To answer the purpose of the first study used qualitative analysis. (2) To answer the purpose of the second and third research used qualitative analysis.

\section{Result and Discussion}

Tulung Agung regency located in the southern part of East Java Province. The population of Besuki sub-district at the end of 2010 was 36,374 people, divided into 18,239 inhabitants and 18,135 in the female. The number of Teenage a Work Indonesia (TKW) Besole village as many as 97 people in 2010 with an area of 3.44 .

Of the total population of 150 ex-migrant workers (who have not been recorded because they are still estimates) and which can be sampled as many as 100 ex-migrant workers have the following description, where there are several aspects or factors studied, among others:

1. Age group

This factor explains that when viewed from the age group, Besole villagers who work as Indonesian workers (TKW) are as follows: age between 41 years to 50 years of 30 people $(30.00 \%)$ From the data shows that most of the villagers Besole working as a female worker (TKW) abroad is between 31 years old and 50 years old, this means that the people working abroad still have the status of productive labor (according to BPS data).

2. Marital status

Marital status explains that Besole villagers who work as female workers (TKW) are a mostly married status that is 94 people $(94,00 \%)$. This means that it meets the requirements of being a requirement 
to become TKW, i.e. one of them if the status of marriage or marriage must get permission from her husband.

3. Level of education

The level of education explains that Besole villagers who work as migrant workers abroad are mostly elementary school (SD), yes that as many as 38 people (38.00\%) and as many as 36 people (36.00\%) are junior high school graduates. From these data indicate that Besole villagers who work as Indonesian laborers and work abroad are mostly educated elementary school (elementary) and junior high school. This means that the majority of Besole villagers who work as Indonesian workers abroad have low education and quality as they are.

4. Working Group

In the sample nature of research, most of them are working as a housewife, as many as 45 people $(45.00 \%)$, as a former, many as 33 people $(33.00 \%)$. The data shows that Besole villagers who work as Indonesian labor abroad mostly work as housewives. Data also reveals that the majority of the Indonesian workers who work abroad are women (mothers). This status is very attached to the opinion that women are mostly poor so that women are always dependent on men.

5. The reason for traveling (being a TKW)

There are several reasons why the Besole villagers chose to become migrant workers abroad. These reasons include: (1) Changing the fate (because of the economy) the number of respondents as many as 87 people $(87.00 \%)$. From these data explain that Besole villagers choose to become TKW for reasons of wanting to change their fate or because of their economy and the reason to finance family life. This means that $87.00 \%$ of respondents are targeted to illustrate that they live below the poverty line (or can be said as a poor group).

6. Country of destinations

Most migrant workers from villages Besole who choose to work in Saudi Arabia and the Middle East as many as 40 people or $40.00 \%$. To Malaysia as many as 19 people or $19.00 \%$, to Singapore as many as 17 people or $17.00 \%$, to Taiwan as many as 12 people or $12.00 \%$, to Hong Kong 8 (eight) or $8.00 \%$ and to Brunei Darussalam as many as 4 (four ) person or $4.00 \%$. This shows that the State of Saudi Arabia is still a favorite country which is the main goal of migrant workers to work. And the least desirable country is Brunei Darussalam.

7. Departure Agency (PJTKW)

Most Besole villagers who choose to work as maids, going abroad through the private recruitment agency, as many as 67 people $(67.00 \%)$ and through state-run recruitment agency many as 33 people $(33.00 \%)$. This shows that the migrant workers know or know about work abroad that mostly come from employees of PJTKI neighbors or other parties. And they set out to prefer to choose through private institutions because it is easier in taking care of the requirements to become TKW. And they are more trustworthy to private sending agencies than government agencies.

8. Costs Expired to Become TKW

For becoming migrant workers must pay a fee for the administrative management and others. The cost of each TKW is not the same. Average costs incurred are less than Rp 1,000,000.00 and some

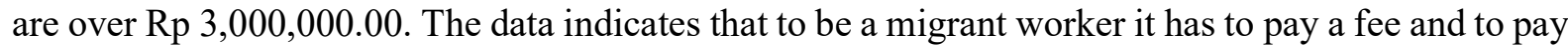
the fee most of the TKW source from loan or debt. So they have to refund the funds. There are forms of loans that come from employment agencies (PJTKI) and some are looking for loans in banks or in loan sharks, so they are very difficult to get out of this job if anything happens with them at work (e.g. working on abusive employers, rapists and stingy).

9. Type of Occupation Abroad

Most of Indonesian workers abroad to work as domestic servants. This is shown by the data of the research results of 100 samples of 88 people working as housemaids or $88.00 \%$ and 12 people or $12.00 \%$ working in other sectors. This shows the level of education owned by teenage working in Indonesia who work abroad is low just graduating elementary school, then the type of work that can be done is as a housekeeper. And the risks that must be faced to become domestic servants are also 
very large, such as a cruel employer, if against unpaid wages, joining a stingy employer (paying salary once a year), male employers who like to rape, cruel employer's son and etc.

10. Earnings / Wages

The amounts received by workers working abroad are as follows: (a) Wages less than Rp $2,000,000.00,42$ persons or $42.00 \%$. (b) Wages / income between Rp 2,000,000.00 to Rp $3,000,000.00$ as many as 34 people $(34.00 \%)$. (c) Wages / income above Rp 3,000,000.00 as many as 24 people $(24.00 \%)$. This data explains that after becoming TKW income or wages received them more than before leaving for TKW. Their welfare level will increase or increase.

11. Years of service

TKW who work abroad with the working period are as follows: (1) Working period of 1 (one) year as many as 12 people (12.00\%). (2) The working period of 2 (two) years as many as 45 people $(45.00 \%)$. (3) Working period of 3 (three) years as many as 18 people $(18.00 \%)$. (4) Working period of 4 (four) years as many as 13 people (13.00\%). (5) Working period of more than 4 (four) years as many as 12 people $(12.00 \%)$. From the data can be explained that most of TKW from Besole village work for 2 (two) years of the contract period. After that, they can work again by renewing the contractor they work to another place with a new contract.

12. How to Pay the Departure Fee

The large fees that have been issued by TKW and that must be borne by TKW to be able to work abroad with the payment system for the cost is as follows: (a) With monthly installment 80 respondents $(80.00 \%)$. (b) Paid upon return or termination of his employment contract by 20 respondents $(20.00 \%)$. (c) The data indicate that the majority of TKWs working overseas to cover the costs incurred to work overseas are to repay each month's wage/salary they receive (cut wages/salary/income).

13. Total Family Count

The number of family dependents to be borne by the ex-migrant workers are: (a) Less than 2 (two) persons as many as 5 (five) respondents $(5.00 \%)$, (b) 2 - 3 persons 32 respondents $(32.00 \%)$, (c) 4 5 people as many as 53 respondents $(53.00 \%)$, (d) More than 5 (five) persons as many as 10 (ten) respondents $(10.00 \%)$. The data shows that the number of dependents of most families is between 4 - 5 people as many as 53 people. With the large number of dependents of the family that is one of the factors causing them to choose a job as TKW.

14. Earnings are Shipped to All Families

The income or income received by these migrant workers is used to meet the needs of the family, so that income is sent to the family in his hometown. Of 74 respondents who gave the answer "YES" which means that the income received is sent entirely to the family of 83 people $(83.00 \%)$. And that gives the answer "NO" which means that the received income is sent entirely to the family of 17 people $(17.00 \%)$. This means that the maids are very much in need of the work. Because of the results, they work will be used to finance the lives of the migrant workers and their families.

15. Use of Wages / Income

The income received by the maids are mostly used to support a family or to meet the economic needs of their families back home as many as 73 people (73.00\%), is used to build houses as many as 19 people (19:00\%), is used to buy a boat as much as 4 (four) people (4.00\%) and used to buy land as many as 4 (four) people (4.00\%). This means that the lives of the migrant workers below the poverty line are more numerous than those who live in prosperity. Poverty is one factor that causes Besole villagers to choose to work as migrant workers.

16. Enjoy from Work As TKW

A total of 92 respondents $(92.00 \%)$ gave answers to enjoy the results of their work as migrant workers and as many as 8 (eight) people (8.00\%) did not give an answer. This data explains that out of 100 respondents, most of them share their work as TKW.

17. Wages Used for Saving 
A total of 32 respondents or $32.00 \%$ answered that the income or wages they received were used for saving and as many as 60 respondents or $60.007 \%$ answered that the income or wages they received was not used to save and as many as 8 (eight) respondents or $8.00 \%$ did not give an answer whether the income they received was used to save or not.

18. Reason No Longer Being TKW

From 100 respondents gave their answers to the reason why they no longer become migrant workers as follows: (a) Due to a family of 52 people $(52.00 \%)$, (b) As tired as many as 14 people (14:00\%), (c) For further age of $21(21.00 \%)$, (d) Upon marriage of 3 (three) persons (3.00\%), (d) For other reasons as many as 10 (ten) persons $(10.00 \%)$. The data explains that most migrant workers are no longer interested in working as migrant workers for family reasons in the sense that they do not want to be away from their families, they do not want to leave their husbands, children, and parents anymore.

19. The Desired Job After No Longer Become a TKW

Of the 100 respondents who were sampled to answer the question of what job they wanted after no longer become TKW, among others: (a) As a trader as many as 24 people $(24.00 \%)$, (b) As a farmer of 19 people (19.00\%), c) As farm laborers as many as 6 (six) persons (6.00\%), (d) As housewife as many as 29 people $(29.00 \%$ ), (e) As a baby sister of 7 (seven) people $(7.00 \%)$, ) As educators as many as 4 (four) persons $(4.00 \%)$, (g) As entrepreneurs as many as 6 (six) persons $(6.00 \%)$, (h) Others as many as 5 (five) persons (5.00\%). The data show that after they are no longer TKW, they still want to work and most of them choose to work as housewives (24 people or $24.00 \%$ ). This means that they want to go back to their nature as housewives or take care of their family because for them more important family even they decided use proverb though golden rain in the country of people more rain stones in their own country or Javanese term eat not eat as long as get together.

20. Revenue After Not Being TKW.

How about the income conditions received or obtained or produced by the respondent after no longer a TKW? These conditions are: (a) Revenue obtained perfunctory means not fixed as much as 27 people $(27.00 \%)$. (b) Revenue earned less or not able to meet the daily requirement of 36 people $(36.00 \%)$. (c) Revenue earned is sufficient to meet the daily needs of 21 people $(21.00 \%)$. (d) Revenue earned is less than when it becomes TKW of 5 (five) persons (5.00\%). (e) Revenue earned is better than 5 (five) persons $(5.00 \%)$, (f) Revenue earned is 6 (six)) $(6.00 \%)$. The data explains that the majority of female migrant workers who choose the decision not to be migrant workers and who choose to work again in their home village earn on average earning less than the income they earn when they become TKW. This will have an impact on their lives.

21. Employment Prospects After Not Being TKW

Of the 100 respondents asked about the prospect of the job after being no longer a TKW, the answer is as follows: (a) A total of 35 respondents (35.00\%) answered the prospect is not good. (b) A total of 31 respondents $(31.00 \%)$ answered their prospects no better. (c) A total of 11 respondents $(11.00 \%)$ answered the prospect was normal. (d) A total of 4 (four) respondents $(4.00 \%)$ responded the prospect tolerable. (e) A total of 3 (three) respondents (3.00\%) answered the prosecution well. (f) A total of 16 respondents $(16.00 \%)$ answered better prospects.

22. Mixed Hand Government When Becoming TKW

Of the 100 respondents who were subjected to the study gave answers to the question of how the government intervened after being a migrant worker, the answer was as follows: (1) There were 32 (32.00\%) government intervention, (2) No government interference as many as 68 people ( $68.00 \%)$. 23. Government Arrangement After Not Being TKW

The related with how government intervention on the fate of migrant workers who have chosen to no longer be the maids was as follows: (a) There is a government intervention as many as 15 people $(15.00 \%),(b)$ There is no government interference as many as 71 people $(71.00 \%)$, (c) Not responding as many as 14 people $(14.00 \%)$ 
Comparison of Life Before Becoming TKW, When Being TKW and After Being TKW. Most of the TKW from Besole village are women. The economic conditions experienced by them before, when and after are no longer TKW can be seen in the following results:

1. Work Before, Moment and After Not Being TKW

Indicating that the type of job chosen before becoming TKW is $45.00 \%$ as a housewife and when become TKW is $88.00 \%$ and after becoming TKW is a housewife as much $29.00 \%$. This means that after no longer a migrant worker the majority of respondents choose to return as housewives. (Source: Factors 4, 11 and 21).

2. Economic Condition Before, Moment and After Being TKW

Shows the comparison that after no longer a TKW $62.56 \%$ of respondent's economic conditions lack, $12.16 \%$ respondents' economic conditions enough, $4.05 \%$ of respondents' good economic conditions and $21.62 \%$ of respondents better economic conditions. The result of this economic comparison shows that the respondents who use the money from their work abroad partly to save, the economic condition will be better after they make the choice to no longer be TKW, but if the respondent who used as the object of research at work as TKW do not use some of their wages to save, then after no longer work as migrant workers economic conditions will be worse than when they become migrant workers.

Therefore, government directives and interventions are needed on the former migrant workers so that their life will increase to become a decent life. This interference is one form of government attention to the former migrant workers who at the time they work as migrant workers have provided a substantial foreign exchange for the government, especially the government of Tulung Agung Regency.

Problems Encountered by The Former TKW. Tulung Agung regency is one of the districts in East Java Province that contributes the most to local revenue, which is derived from foreign exchange sent by the migrant workers who work abroad. These foreign exchange contributors are an asset to the district government while they are still working. However, the problem arises when they are no longer a TKW, namely: (1) Economic conditions that go back to the time before leaving for TKW. (2) There is no concern from the government towards the migrant workers who are no longer TKW, (3) the difficulty of finding employment or business field in their own country, (4) Physical which no longer guarantees them to keep working as TKW. (5) Lack of appreciation given by the government after they are no longer TKW. (6) Their trauma to become TKW again. (7) Unstable economic conditions in the State of Indonesia. (8) The quality of human resources is still low. (9) High cost or cost to become TKW. (10) Often used as the object of dispute by the government at home and abroad. (11) Ineffective protection for migrant workers working overseas in obtaining a sense of security and comfort in working.

How Former Migrant Workers and Local Government in Overcoming the Problems of Former Migrant Workers. How Former TKW Faced Such Problems. The former TKW workers in Besole village have their own ways of dealing with or resolving the problem, among others: (1) to return to work as before they become TKW, (2) Become self-employed by using some wages that have been saved as TKW ( 3) Being a domestic helper, (4) Attending training organized by local government and central government (5) Opening own business, (5) Becoming farmers and farm workers, (6) Becoming baby sister, (7) tailor, (8) Unlock beauty salon, (9) Open bridal makeup, (10) Become a trader, (11) Become educator or teacher.

How the Government Facing or Resolving Problems Former TKW. The problems faced by the Tulung Agung district government, especially Besole village government, do not have data on the number of migrant workers and ex-migrant workers, this is because there are migrant workers who leave for their work not through Besole village government but through other villages and subdistricts. Likewise, with the service companies. TKW used by TKW to go to work abroad is not entirely in Tulung Agung District, so to record the number of TKW from Tulung Agung district is 
valid very difficult. Moreover, data on the number of former TKW who no longer work as TKW, not found data.

Therefore with this research is actually very helpful to the government of Tulung Agung district and Besole village government in particular to get data about the number of TKW and former TKW is actually (valid). From this research the number of former migrant workers who have been registered as many as 100 people from $150 \mathrm{TKW}$ people who came from the village Besole. Of the 100 respondents of former TKW average, they give the same answer that they never get attention from local government after they no longer become TKW.

From the results of this study, it is found that these former migrant workers do not get the attention of the government for the following reasons: (1) The government does not have data on the number of former TKW, (2) The migrant workers who have not worked as TKW never report to RT / RW or local village government, (3) RT / RW and village government have never conducted data collection on the number of TKW and former TKW.

Because of this condition, the former TKW has never been touched by the policies of the central government or local government. It is very ironic of the fate of the maids. On one side at the time of becoming TKW is the biggest contributor of PAD but after no longer become TKW their fate is very concern.

From the results of this study is expected between the central, regional and village governments have a symbiotic relationship of mutualism in solving the problem of the TKW. Measures and policies related to the fate of the migrant workers should be the government's attention. One of the actions that should be done by the government, especially the local government is to provide special allocation for training and capital for ex-migrant workers. This needs to be done because to improve the welfare and standard of living of ex-TKW.

\section{Conclusion}

From the results of this study can be concluded several things as follows: (1) Not regularly data about TKW, (2) Unclear use of rules about TKW, (3) Many unclear statuses of Service Company TKW, (PJTKI) in Tulung district Agung in particular or other districts in Indonesia. (4) In the absence of a clear status of PJTKI, there are several things that arise, among others: (a) The fate of the maids who are less clear after being sent abroad. (b) The protection of health, safety, and comfort of migrant workers abroad is lacking or even nonexistent, (c) Data on abandoned migrant workers abroad is less transparent or difficult to find if not to PJTKI agencies. (5) Data about migrant workers and ex-TKW not found. (6) The absence of policies from central and local governments that are directly related to former TKW.

Suggestion.

1. There needs to be valid data about migrant workers in order to know the number of migrant workers who go abroad to the destination country and the purpose they work there by the government.

2. It is necessary to make valid data about the former migrant worker so that it is necessary to take a policy related to the former TKW.

3. There needs to be a hierarchical relationship between the central government, the regions and the villages that are associated with TKW and former TKW.

4. The need to issue special policies related to the fate of former migrant workers by the central and regional governments.

5. Central or local governments need to provide jobs and work for former migrant workers by providing training, capital and permitted facilities and so on.

6. There needs to be special government intervention on the fate of the former TKW.

The limitation of this study is that research is conducted only in one of the districts that give the largest contribution in the departure of Women Laborers abroad. 


\section{References}

BPS (2017a) 'IDG Jatim', in Badan Pusat Statistik. Jakarta: Central Bureau of Statistics. Available at: https://jatim.bps.go.id/dynamictable/2017/09/19/94/indeks-pelpdayaan-gender-idg-menurutkabupaten-kota-2010-2015.html.

BPS (2017b) 'Number of Job Seekers, Work Placements and Demand by Gender Year 2012-2016', in BPS. Surabaya: BPS East Java Province. Available at: https://jatim.bps.go.id/statictable/2017/06/09/461/jumlah-pencari-kerja-penempatan-kerjadan-perms-menurut-jenis-kelamin-2012-2016.html.

BPS (2017c) 'Population by Main Employment 1986-2017', in Central Bureau of Statistics. Jakarta: Central Bureau of Statistics. Available at: https://www.bps.go.id/statictable/2009/04/16/970/population-15-years-to-the-that-work-workwork-work-products-main-1986-- -2017.html.

BPS Jakarta, 2002, Women's Social Indicator DKI Jakarta, Jakarta.

BPS Jakarta, 2000, Methodology of Poor Household Determination , Jakarta.

Khusnatul Zulfa Wafirotin, 2013, Impact of Migration on Social Economic Condition of TKI's Family in Babadan Sub-district, Ponorogo Regency, Journal of Equilibrium, Volume 11, Number 2, March 2013.

Kiaušien e , I. (2015) 'Comparative assessment of women unemployment and poverty in European Union', Intellectual Economics , 9 (2), pp. 91-101. doi: 10.1016 / j.intele.2015.12.001.

Kuntjoro-Jakti, Dorodjatun, 1986, Kemiskinan di Indonesia, Jakarta: Yayasan Obor Indonesia.

Latifah, E. (2010) 'Harmonization of Poverty Alleviation Policy In Indonesia Oriented to the Millennium Development Goals .', Eprints.Uns.Ac.Id, pp. 391-401. Available at: http://eprints.uns.ac.id/11556/.

Meinzen-Dick, R. et al. (2017) 'Framework and review of the available evidence', Agricultural Systems. Elsevier, (October), pp. 1-11. doi: 10.1016 / j.agsy.2017.10.009.

Nizar, C., Hamzah, A. and Syahnur, S. (2013) 'The Effects of Investment And Labor On Economic Growth And Its Relation To Poverty Level In Indonesia', Journal of Economics, 1 (2), pp. 1-8. doi: $2302-0172$.

Satria, D. (2009) 'Ecotourism Development Strategy Based on Local Economy in the Framework of Poverty Reduction Program in Malang Regency Area', Journal of Indonesian Applied Economics, 3 (1), pp. 1-2009. doi: 10.21776 / ub.jiae.2009.003.01.5.

Sayekti Suindyah Dwiningwarni (2016) 'Ex-Migrant Worker: An Assessment Problem (Study in The District of Tulung Agung)', in International Conference on Economics, Business and Social Sciences (ICEBUSS) 2016. Malang: Faculty of the Economics University of Islam Malang, p. 122. Available at: http://icebuss.org/download/.

Tjiptoherijanto, Prijono, et al, 1982, Human Resources, Employment and Economic Development, Jakarta: LP 